Article

\title{
High-Efficiency p-Type Si Solar Cell Fabricated by Using Firing-Through Aluminum Paste on the Cell Back Side
}

\author{
Guang Wu ${ }^{1,2}$, Yuan Liu ${ }^{1, *}$, Mengxue Liu ${ }^{2}$, Yi Zhang ${ }^{2}$, Peng Zhu ${ }^{1, *}$, Min Wang ${ }^{3}$, \\ Genhua Zheng ${ }^{3}$, Guangwei Wang ${ }^{3}$ and Deliang Wang ${ }^{3, *}$ \\ 1 College of Chemistry and Chemical Engineering, Nantong University, 226019 Nantong, China; \\ SA226148@mail.ustc.edu.cn \\ 2 Nano Science and Technology Institute, University of Science and Technology of China, 230026 Hefei, China; \\ lmxlmx@mail.ustc.edu.cn (M.L.); zyjw@mail.ustc.edu.cn (Y.Z.) \\ 3 Hefei National Lab for Physical Sciences at Microscale, University of Science and Technology of China, \\ 230026 Hefei, China; min@mail.ustc.edu.cn (M.W.); zghno1@mail.ustc.edu.cn (G.Z.); \\ wangggw@mail.ustc.edu.cn (G.W.) \\ * Correspondence: liuyuan1105@ntu.edu.cn (Y.L.); pzhu@ntu.edu.cn (P.Z.); eedewang@ustc.edu.cn (D.W.); \\ Tel.: +86-1377-170-2680 (Y.L.); +86-1380-908-8268 (P.Z.); +86-551-63600450 (D.W.)
}

Received: 26 September 2019; Accepted: 14 October 2019; Published: 17 October 2019

check for updates

\begin{abstract}
Firing-through paste used for rear-side metallization of p-type monocrystalline silicon passivated emitter and rear contact (PERC) solar cells was developed. The rear-side passivation $\mathrm{Al}_{2} \mathrm{O}_{3}$ layer and the $\mathrm{SiN}_{\mathrm{x}}$ layer can be effectively etched by the firing-through paste. Ohmic contact with a contact resistivity between 1 to $10 \mathrm{~m} \Omega \cdot \mathrm{cm}^{2}$ was successfully fabricated. Aggressive reactive firing-through paste would introduce non-uniform etching and high-density recombination centers at the Si/paste interface. Good balance between low resistive contact formation and relatively high open-circuit voltage can be achieved by adjusting glass frit and metal powder content in the paste. Patterned dot back contacts formed by firing-through paste can further decrease recombination density at the Si/paste interface. A P-type solar cell with an area of $7.8 \times 7.8 \mathrm{~cm}^{2}$ with a $\mathrm{V}_{\text {oc }}$ of $653.4 \mathrm{mV}$ and an efficiency of $19.61 \%$ was fabricated.
\end{abstract}

Keywords: firing-through paste; PERC; contact formation; open-circuit voltage

\section{Introduction}

In the last two decades the efficiency of large-area crystalline Si solar cells has been increased significantly. The efficiency increase was mainly ascribed to the new concepts introduced to the crystalline Si solar cell structure, such as passivated emitter and rear contact (PERC), heterojunction with intrinsic thin layer (HIT), and tunnel oxide passivated contact [1-3]. In industry, the structure of full-area aluminum-back-surface-field $\mathrm{Si}$ solar cell has been gradually replaced by a PERC structure solar cell [4-7]. For a PERC Si solar cell, the first step to make back contact at the rear side of a Si wafer with passivation layer stack is laser contact opening (LCO) [8-10], namely, using a laser to remove the passivation layer. Then, a full area Al layer is screen-printed. In this way, good quality contact can be achieved at the LCO area [11-13].

Local contact openings in a PERC solar cell can be made by printing etching paste [14], laser ablation, photolithography or mechanical scribing [15]. Laser ablation has been considered to be one of the best candidates for fabricating an industrial PERC cell. Laser processing eliminates physical contact, thus minimizing the probability of contamination. Laser processing speed can be extremely 
fast enabling high-throughput processing. This is unattainable by mechanical techniques such as mechanical scribing [16].

For both PERC and bifacial PERC solar cells, low rear-side contact resistivity between paste and Si-substrate is necessary for the fabrication of a high efficiency solar cell. Good contact between paste and substrate depends on many factors, such as Si substrate doping type, LCO size, metallization process and Al paste [17-22]. Picard E et al. studied the metallization condition and its effect on the voids formation at the $\mathrm{LCO}$ which affect solar cell $\mathrm{V}_{\mathrm{oc}}$. A $\mathrm{V}_{\mathrm{oc}}$ value of the PERC cells was reached at $665 \mathrm{mV}$. Better electrical performance parameters are limited by the front-side surface and the Si-bulk recombination [20]. Rauer $\mathrm{M}$ et al. demonstrated that contact penetration into the Si bulk can be reduced and the thickness of the Al- $\mathrm{p}^{+}$region in the LCO area can be enhanced by intentionally adding some Si particles to the Al paste [23].

According to our results, we demonstrate that metallization on the rear side of a PERC solar cell can be efficiently achieved by the fire-through contact (FTC) method [24]. The passivation stack at the rear side of a PERC solar cell can be etched and/or reacted with $\mathrm{Al}$ paste and form a good back contact without a laser opening process, and the progress of making PERC solar cells would be much easier and cheaper [24-27]. The integration of the FTC approach into metal wrap through solar cells is presented in Thaidigsmann's research, different FTC contact geometries and printing approaches are investigated [24]. Dominik Rudolph et al. developed an aluminum firing-through paste for the rear side metallization of p-type bifacial multicrystalline solar cells. The experimental results showed that the boron doping underneath the passivation stack is helpful to reach a good passivation quality and contact formation.

In this work, the firing-through paste can efficiently etch or react with the passivation stack and form a local back-surface field (BSF), and achieving a low specific contact resistivity $\rho_{\mathrm{c}}$ for $1.1 \mathrm{~m} \Omega \cdot \mathrm{cm}^{2}$ with a $V_{\text {oc }}$ for $647.3 \mathrm{mV}$. We also demonstrate that low-resistance rear side metallization can be achieved by first applying a glass paste layer on the rear side of a PERC solar cell to effectively react with the passivation layers, and $\mathrm{Al}$ paste can then be applied on the etched area. Point contact formed by firing through process can further reduce contact formation uniformity and improve PERC solar cell efficiency. In this study a p-type PERC solar cell with an area of $7.8 \times 7.8 \mathrm{~cm}^{2}$ with a $\mathrm{V}_{\text {oc }}$ of $653.4 \mathrm{mV}$ and an efficiency of $19.61 \%$ was fabricated.

\section{Materials and Methods}

Semi-finished PERC solar cells with area of $78 \times 78 \mathrm{~mm}^{2}$ were fabricated by Trina Solar Limited Company. The PERC solar cell has a structure of $\mathrm{SiN}_{x}(80 \mathrm{~nm}) / \mathrm{n}^{+}-\mathrm{Si} / \mathrm{p}-\mathrm{Si} / \mathrm{Al}_{2} \mathrm{O}_{3}(10 \mathrm{~nm}) / \mathrm{SiN}_{x}(80 \mathrm{~nm})$. Cz-Si p-type wafers with a resistivity of $\sim 1 \Omega \cdot \mathrm{m}$ and a thickness of $\sim 150 \mu \mathrm{m}$ was employed for solar-cell fabrication. The $\mathrm{SiNx}$ and $\mathrm{Al}_{2} \mathrm{O}_{3}$ layers were prepared by plasma-enhanced chemical vapor deposition (PECVD). In this study, laser opening was not applied at the Si cell back side.

The firing-through pastes made in this study was composed of organic binder, glass frit, and $\mathrm{Al}$ powder or Al-Si eutectic metal powder. First, the paste components were mixed in a plastic jar, then the plastic jar was put into a high-speed centrifugal machine to mix the paste well. The mixed materials were dispersed on a roll mill to fully mix together the components of the paste. In this study 4 types of pastes were fabricated, and we named them paste 1,2,3, and 4 . Paste 1 and 2 were made of the same glass frit using different conductive powder, Al-Si eutectic metal powder for paste 1 and Al powder for paste 2, respectively. Paste 2, 3 and 4 were made of the same Al powder component but with three different kinds of glass frits. The glass frits in paste 2, 3 and 4 were made of the same oxides using different weight ratio among the oxides. The oxides in the glass frit were $\mathrm{PbO}, \mathrm{SiO}_{2}, \mathrm{ZnO}, \mathrm{Li}_{2} \mathrm{CO}_{3}$, $\mathrm{Cs}_{2} \mathrm{CO}_{3}, \mathrm{Sb}_{2} \mathrm{O}_{3}$ and $\mathrm{H}_{2} \mathrm{BO}_{3}$. The different weight ratio among the oxides can get glass powder with different reaction ability. The main component of change was $\mathrm{PbO}$ and $\mathrm{SiO}_{2}$, and the best percentage of $\mathrm{PbO}$ and $\mathrm{SiO}_{2}$ in the glass frit was $\mathrm{PbO}: 50-60 \mathrm{wt} . \%, \mathrm{SiO}_{2} 5-10 \mathrm{wt} . \%$. The firing-through paste was screen-printed on the back side of Si PERC solar cells and then dried for $3 \mathrm{~min}$ at $200{ }^{\circ} \mathrm{C}$ in an oven in 
the atmosphere. The solar cell front Ag grid was then screen-printed, and finally the finished PERC solar cells were fired in a belt furnace with a peak temperature at $\sim 750^{\circ} \mathrm{C}$.

The solar cell current-voltage $(\mathrm{J}-\mathrm{V})$ curves were measured under the standard AM1.5 illumination $\left(1 \mathrm{~kW} / \mathrm{m} 2,25^{\circ} \mathrm{C}\right)$ on a solar J-V tester (IVT Solar Pte Ltd., Shanghai, China). The contact resistivity was measured by transfer-line measurements (TLM) on 10-mm-width stripes with equidistant metallization lines. The morphology of the pastes and the microstructures of the cells were all characterized by using a field-emission scanning electron microscope (FE-SEM, Sirion 200, HITACHI, Tokyo, Japan). The firing through reaction phenomenon at the paste/ $\mathrm{SiN}_{\mathrm{x}} / \mathrm{Al}_{2} \mathrm{O}_{3} / \mathrm{Si}$ interface was studied by using micro-Raman scattering. Raman spectra were recorded in a backscattering configuration using a Renishaw Micro-Raman spectrometer (Blue Scientific, Cambridge, UK). The laser lines $532 \mathrm{~nm}$ (solid state green laser) was used as the excitation sources. The laser light spot was fixed to a size of about $1 \mu \mathrm{m}$.

\section{Results}

Currently the chemical composition of an aluminum paste used for full-area back side metallization on a $\mathrm{Si}$ wafer cannot fire through the passivation stack, which is usually composed of an $\mathrm{Al}_{2} \mathrm{O}_{3}$ and a $\mathrm{SiN}_{\mathrm{x}}$ layer. It is necessary to develop paste that can fire through the $\mathrm{Al}_{2} \mathrm{O}_{3} / \mathrm{SiN}_{\mathrm{x}}$ bilayer stack without laser opening. Figure 1a shows the PERC solar cell back-side metallization fabrication process. For the fabrication of conventional bifacial $\mathrm{Si}$ PERC solar cell, the $\mathrm{Al}_{2} \mathrm{O}_{3} / \mathrm{SiN}_{\mathrm{x}}$ passivation layer stack at the back side of a PERC solar cell is first removed by a laser-opening process, and then Al paste is screen-printed on the laser opening area. Then the solar cell module was heat treated at a relatively high temperature to achieve contact metallization and form a back surface field. In this study firing-through paste was designed to react with the $\mathrm{Al}_{2} \mathrm{O}_{3} / \mathrm{SiN}_{\mathrm{x}}$ stack and then form a back surface field layer in the Si substrate, as shown in Figure 1b. In this case, the laser opening was not needed. This simplifies the cell fabrication process and would reduce the solar-cell fabrication cost. Figure 2a shows the pattern of firing-through paste screen-printing on the rear side. For this study, Figure $2 b$ shows the photograph of a finished solar cell with back contact fabricated by using firing-through paste which was screen-printed on the cell rear side.

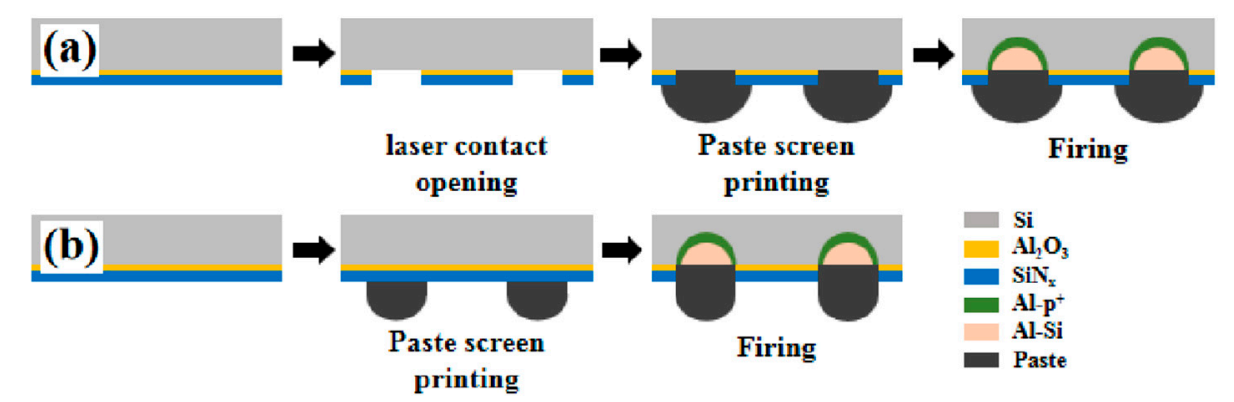

Figure 1. (a) Progress flow for passivated emitter and rear contact (PERC) cell fabrication. In this case contact metallization was assisted by laser opening process; (b) progress flow for PERC cell fabrication by using firing-through paste. In this case laser opening process is not necessary. 

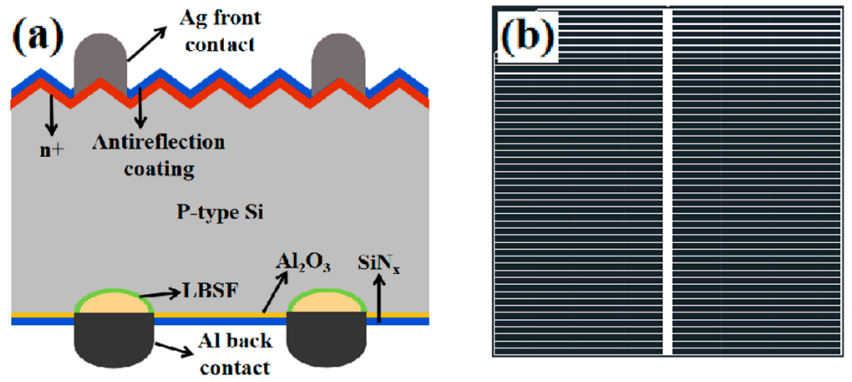

Figure 2. (a) Schematic structure of the solar cell fabricated in this study; (b) the pattern of firing-through paste screen-printing on the rear side.

Firing-through process between $\mathrm{Al}$ paste and $\mathrm{SiN}_{\mathrm{x}}$ layer on a $\mathrm{Si}$ substrate mainly depends on the reactions between the glass frit and the $\mathrm{SiN}_{\mathrm{x}}$ layer at relatively high temperature during the fabrication process of a Si solar cell module. Figure $3 \mathrm{a}, \mathrm{b}$ show the comparative surface morphologies of two cell $\mathrm{Si}$ surfaces after the paste was removed. The two wafers used were first screen printed with the Al paste developed in this study and the conventional PERC Al paste, respectively. The printed fingers had a width of $80 \mu \mathrm{m}$. Then, the two wafers were heat treated at a peak temperature of $750{ }^{\circ} \mathrm{C}$. After the heat treatment, the two wafers were etched in diluted $\mathrm{HCl}$ to etch away the $\mathrm{Al}$ paste. From Figure $3 \mathrm{~b}$ it can be seen that relatively heavy reactions have been occurred between the $\mathrm{Si} / \mathrm{Al}_{2} \mathrm{O}_{3} / \mathrm{SiN}_{\mathrm{x}}$ and the paste. The Si surface coated with the conventional PERC Al paste demonstrated almost no detectable etching effect, as shown in Figure 3a.
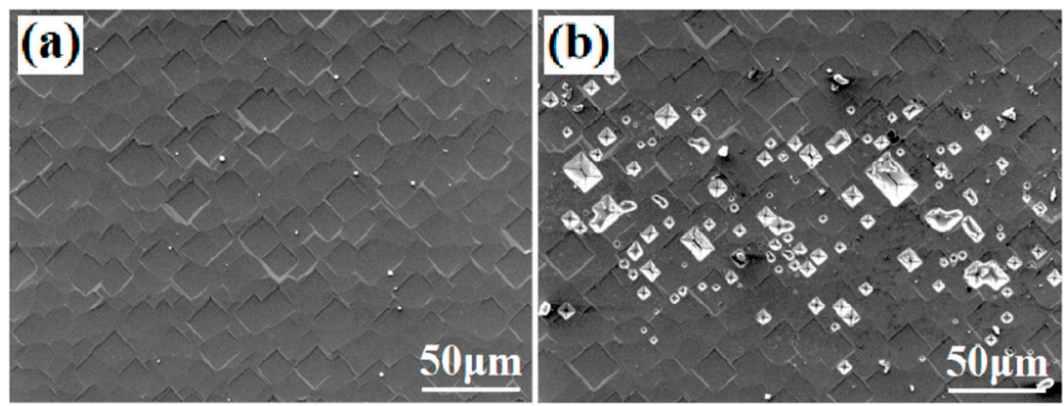

Figure 3. The surface morphologies two cells after the contact pastes were etched away. (a) Cell with conventional PERC Al paste; (b) cell with firing-through Al paste.

In this study, four series of aluminum pastes with different etching capability were developed. The $\mathrm{Si}$ wafer surfaces after firing-through reaction with three different types of paste are shown in Figure 4. It can be seen that the firing-through reaction between the paste and the $\mathrm{Si} / \mathrm{Al}_{2} \mathrm{O}_{3} / \mathrm{SiN}_{\mathrm{x}}$ depended strongly on the different components of the pastes. For the paste 1 and paste 2, the reacted surface area accounted for about $85 \%$ and $30 \%$ of the whole $\mathrm{Al}_{2} \mathrm{O}_{3} / \mathrm{SiN}_{\mathrm{x}}$ stack surface, respectively. For the least reactive paste 4, only sporadic areas had been fired through, as shown in Figure 4e. Element mappings for the reacted areas, which demonstrated "white" color area in Figure 4a, are shown in Figure 5. It can be seen that in the reacted area, the element $\mathrm{N}$ has almost disappeared, as shown in Figure $5 c$, indicating that in this area the $\mathrm{SiN}_{\mathrm{x}}$ was almost reacted with the paste. For the $\mathrm{Al}_{2} \mathrm{O}_{3}$ passivation layer, though with a lower intensity compared to that detected at the neighboring unreacted area, the Al EDS mapping still showed rather intensive signals at the reacted area. This means that a significant part of the $\mathrm{Al}_{2} \mathrm{O}_{3}$ passivation layer remained unreacted. This was confirmed by the following discussions. 

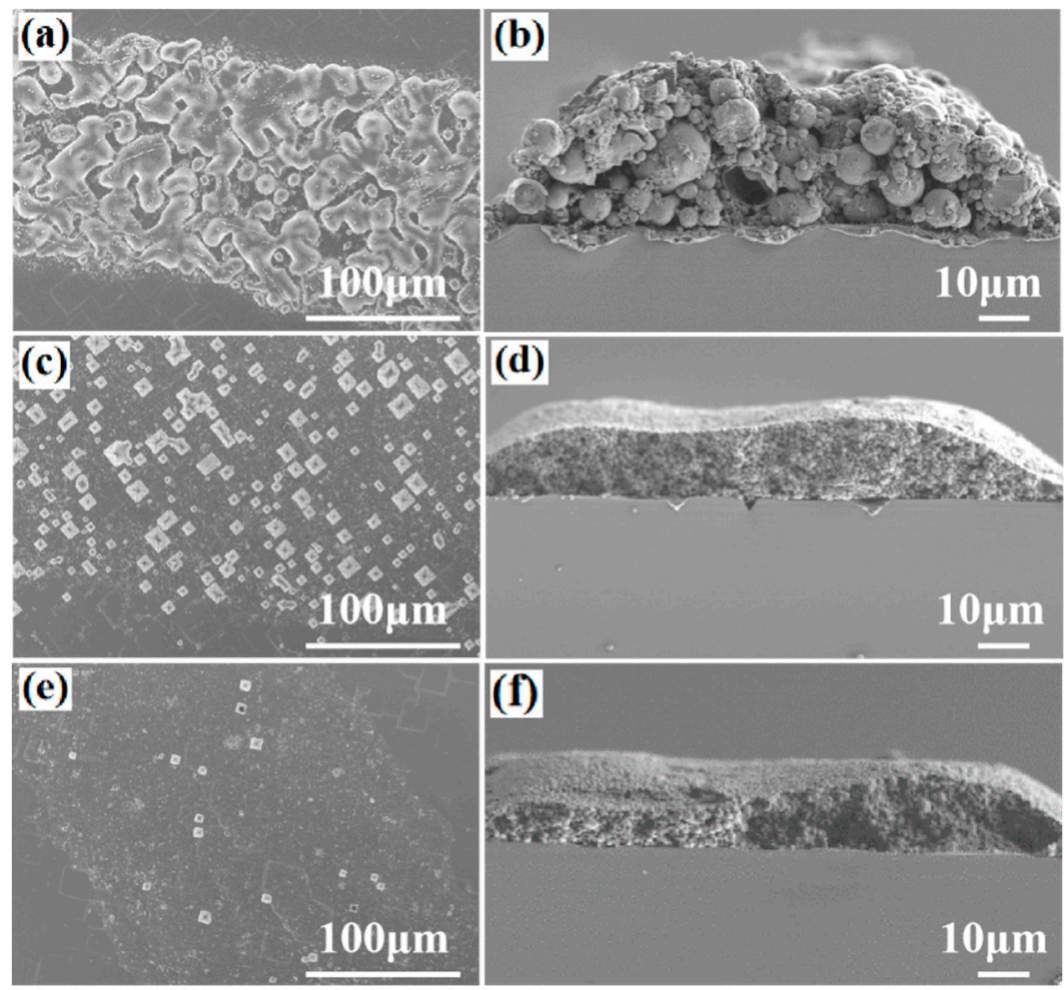

Figure 4. (a,c,e) Surface morphologies of cells with paste 1, 2, 4 after the contact pastes were etched away; (b,d,f) cross section of contact grid lines fabricated with paste 1, 2, 4 .
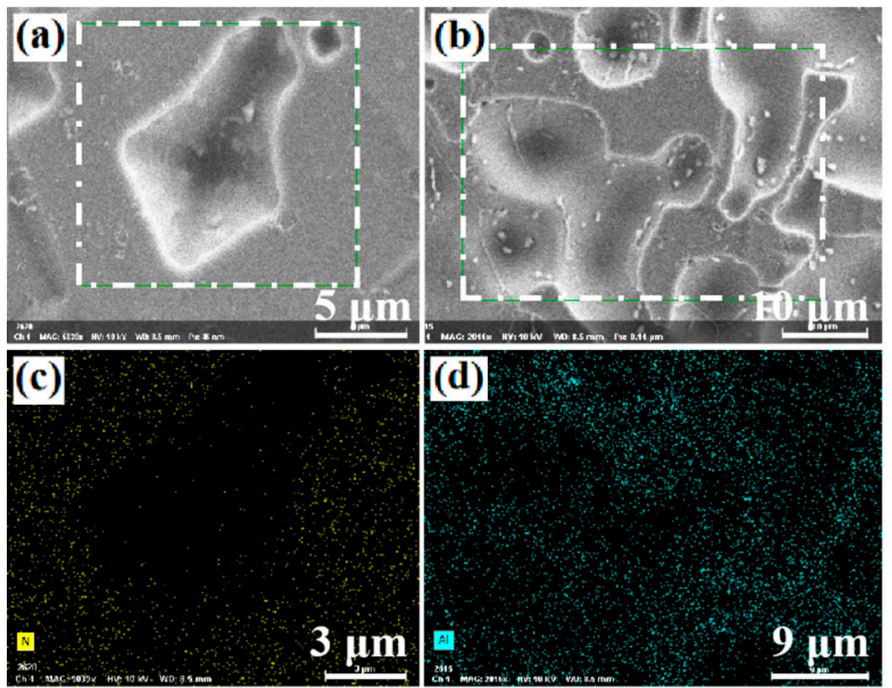

Figure 5. (a,b) scanning electron microscope (SEM) surface images of the reacted areas after the $\mathrm{Al}$ paste 1 had been etched; (c,d) element mapping for nitrogen and $\mathrm{Al}$ at the reacted areas shown in $(\mathbf{a}, \mathbf{b})$, respectively.

The reaction between the firing-through paste and the $\mathrm{Si} / \mathrm{Al}_{2} \mathrm{O}_{3} / \mathrm{SiN}_{\mathrm{x}}$ structure was further studied by Raman scattering measurements, which were taken near the interface of paste/Si wafer. Raman spectroscopy is a sensitive and non-destructive method that can reveal information at atomic scale based on crystalline lattice vibrations. Figure 6 shows the optical microscopy images and the corresponding Raman scattering near the three paste/Si interfaces with different paste types, namely, paste1, paste 2 and paste 4 . The Raman line " 5 " was taken in the Si wafer near the Si/paste interface. The detected areas in all the three samples were marked by the numbers " 5 " in the Si interior bulk wafers. If the detection location was far away from the Si/paste interface, the Raman scattering would 
only reflect the Raman scattering from the bulk Si lattice, namely, the typical phonon-scattering peak of the Si $1 \mathrm{LO}$ peak near $520 \mathrm{~cm}^{-1}$. The relatively broad Raman line " 1 ", which was detected in the paste far away from the Si/paste interface, showed a rather broad peak around the Si $520 \mathrm{~cm}^{-1}$. This peak originated in the Si diffused from the Si substrate during the firing-through reaction. The line " 1 " demonstrated a decreased intensity from paste 1 , to paste 2 and paste 4 . This observation was consistent with the microstructure observations shown in Figure 4. The Raman lines " 2 ", " 3 " and " 4 " were taken at different locations along the $\mathrm{Si} /$ paste interface. If the firing through reactions at the $\mathrm{Si} /$ paste interface were uniform, then the Raman scattering lines " 2 ", " 3 " and " 4 " would be the same, namely, they should be overlapped. For the most reactive paste 1, shown in Figure 6b, the three Raman lines " 2 ", " 3 " and " 4 " showed a relatively large difference both in Raman frequency and line width. The difference among the Raman lines " 2 ", " 3 " and " 4 " also indicates that at the Si/paste interface the interdiffusion/reactions were not uniform in a micro scale. In contrast, for the least reactive paste 4 , shown in Figure $6 f$, the three Raman lines " 2 ", " 3 " and " 4 " almost overlapped with each other, indicating a rather uniform Si/paste interface. As shown in Figure 4c, the firing through reaction for the paste 4 was much less than that of the paste 1 as shown in Figure 4a,b.
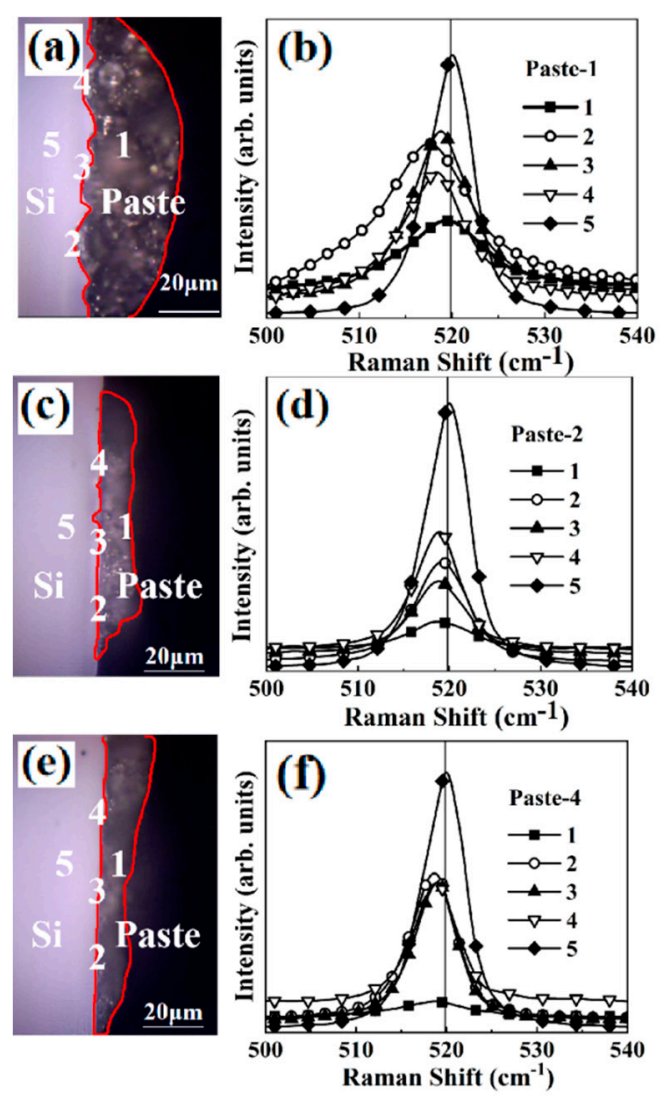

Figure 6. (a,c,e) Optical microscope images of Si/paste interfaces with paste 1, 2 and 4; (b,d,f) Raman spectra of the Si $1 \mathrm{LO}$ detected at different positions near the Si/paste interface. The detected positions are marked as numeric numbers from 1 to 5 in the optical microscope images.

The difference among the Raman lines " 2 ", " 3 " and " 4 " also indicates that at the Si/paste interface the interdiffusion/reactions were not uniform in a micro scale. This was confirmed by the high-resolution SEM observations shown in Figure 7 . Figure 7 shows the Si/paste 1 interface after firing-through reaction in different micro-scale resolution. It can be seen that about $85 \%$ of the Si/paste interface had been reacted after the firing-through process. In the heavily reacted region, it was found that part of the $\mathrm{Al}_{2} \mathrm{O}_{3} / \mathrm{SiN}_{\mathrm{x}}$ did not react with the $\mathrm{Al}$ paste. Figure $7 \mathrm{~b}$ shows that in the heavily reacted region some part of the $\mathrm{Al}_{2} \mathrm{O}_{3} / \mathrm{SiN}_{\mathrm{x}}$ did not react with the $\mathrm{Al}$ paste, rather it was broken due to the reaction of $\mathrm{Al}$ 
with the $\mathrm{Si}$ underneath the $\mathrm{Al}_{2} \mathrm{O}_{3} / \mathrm{SiN}_{\mathrm{x}}$ layer. The uneven ablation area would increase recombination of carriers and reduce the open circuit voltage.

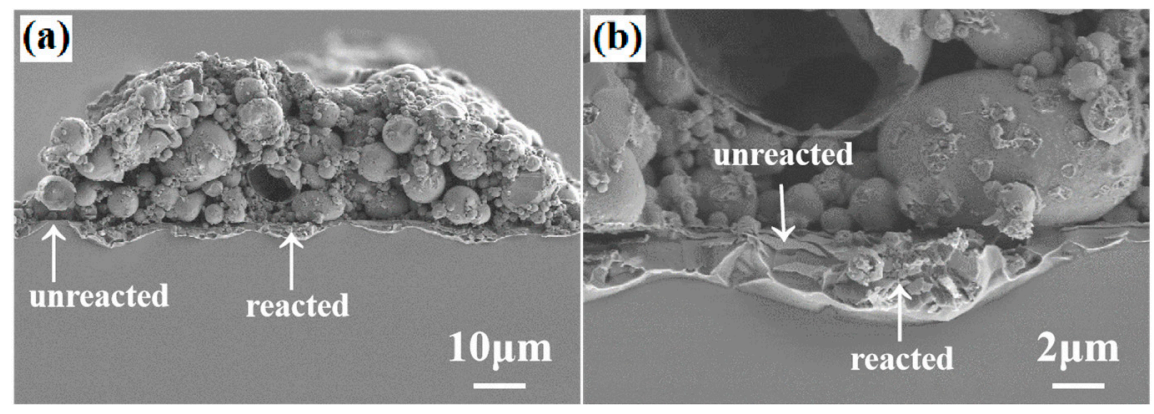

Figure 7. (a) SEM image at the Si/paste 1 interface after firing through reaction; (b) detailed SEM image showing non-uniform reactions at the Si/paste 1 interface.

A back-surface field layer formed by alloying of $\mathrm{Al}$ with $\mathrm{Si}$ was detected by electrochemical capacitance-voltage (ECV) measurements. Localized component detections around a spike, which is about $5 \mu \mathrm{m}$ deep into the $\mathrm{Si}$, were carried out to quantitatively characterize the components of $\mathrm{Si}$ and Al. The EDX data showed that near the spike/Si interface area, significant alloying between $\mathrm{Al}$ and $\mathrm{Si}$ had occurred. This observation was confirmed by the ECV measurement [21,22] shown in Figure 8.

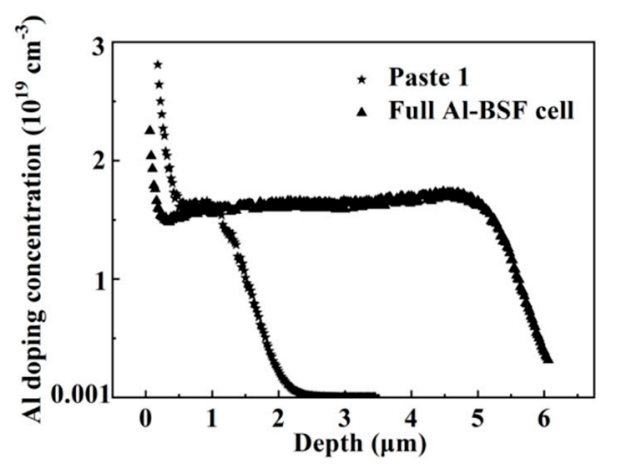

Figure 8. Comparative electrochemical capacitance-voltage (ECV) measurements of the doping profiles obtained in the Si substrates using the firing-through paste 1 and normal full-area Al-back-surface field (BSF) paste, respectively.

Figure 8 shows two Al doping profiles obtained by ECV measurement of a normal full-area aluminum back field cell and a PERC cell fabricated in this study by using Al paste 1 . The full-area aluminum back field cell had no passivation stack layer at the cell back side. Therefore, the reaction between $\mathrm{Al}$ and $\mathrm{Si}$ was fully reacted, resulting in a relatively Al-high doping depth profile of around $5 \mu \mathrm{m}$ into the Si. For the PERC cell with firing through paste 1, it can be seen that the Al doping depth of paste 1 was rather shallow, and the thickness of the BSF was only around $1 \mu \mathrm{m}$. For both the cells, the doping concentrations at the depth range from the surface to $\sim 1 \mu \mathrm{m}$ into the Si substrates were at the same level, namely, $\sim 1.5 \times 1019 \mathrm{~cm}^{-3}$. Such a doping concentration can satisfy the requirement of low contact formation on a Si substrate [20]. From Figure 8 it can be seen that the Al depth and doping uniformity obtained by using the firing-through technique in this study are needed to be further improved compared to the currently dominant full-area Al-BSF paste solar cells.

The J-V curves of the four p-type Si solar cells fabricated with the four different types of Al pastes are shown in Figure 9. The specific contact resistivity $\rho_{\mathrm{c}}$ is $1.1,55.4,124.3$, and $234.1 \mathrm{~m} \Omega \cdot \mathrm{cm}^{2}$ for the four $\mathrm{Si}$ cells with pastes 1 to 4 , respectively. For the most reactive paste 1, it can be seen that a low resistivity $\rho_{\mathrm{c}}$ in the order of $1.0 \mathrm{~m} \Omega \cdot \mathrm{cm}^{2}$ was successfully achieved. Figure $9 \mathrm{~b}$ shows the dependence of the fill factor FF and the open-circuit voltage $V_{o c}$ on the contact resistivity. With a low specific contact 
resistivity, the solar cell fill factor was increased. However, as discussed above and shown in Figure 5, for the solar cell with the most reactive paste 1, the open-circuit voltage was $6 \mathrm{mV}$ lower than that of the cell with the paste 4 . This was induced by the increased carrier recombination at the Si/paste interface. For the Si cell fabricated with paste 4, the Si/paste interface was rather uniform, but the firing-through reaction between the passivation stack and the paste was far less than that of the cell with paste 1 . This led to a much high specific contact resistivity $\rho_{\mathrm{c}}$ of $234.1 \mathrm{~m} \Omega \cdot \mathrm{cm}^{2}$ and low fill factor of $70.1 \%$.
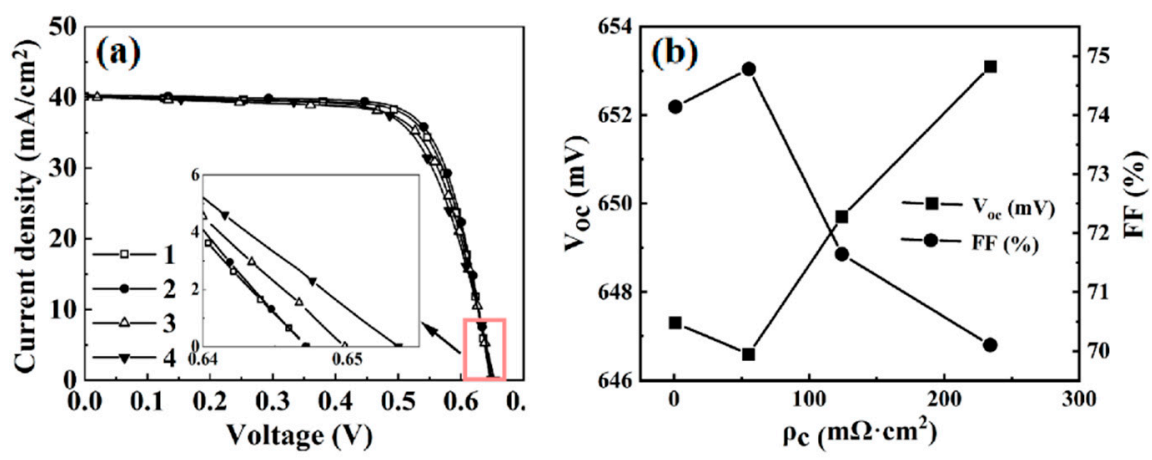

Figure 9. (a) J-V curves of four p-type Si solar cells fabricated with the four different types of $\mathrm{Al}$ pastes; (b) dependence of the fill factor and the open-circuit voltage on the contact resistivity.

It can be seen from this study that the paste 1 is the most reactive paste to fire through the passivation stack. In the $\mathrm{Al}$ paste, the active component to etch the passivation stack was the glass frit. In order to enhance the fire-through etching process, we have made glass pastes, in which $\mathrm{Al}$ was not added. In this case, the glass frit would be more intensely and physically contacted with the passivation stack, while for Al paste, a significant part of the surface of a passivation stack would be occupied by the $\mathrm{Al}$ particles in the paste. $\mathrm{Al}$ particles are not the reactive component for the fire-through process. Therefore, glass frit components would be more critical for Al paste to fire through the passivation stack. In order to demonstrate the etching effect of glass frit on solar cells, two types of glass pastes, in which no $\mathrm{Al}$ was added, were prepared and screen printed on two PERC Si solar cells. The glass frit components in the two glass pastes were the same as that of the glass frit in the paste 1 which makes sure an efficient etching reaction between the glass frit and the passivation stack, as discussed above. The difference between the two glass pastes made in this study was only that the solid glass frit was $10 \%$ and $30 \%$ of the total glass paste, respectively. Figure $10 \mathrm{a}, \mathrm{b}$ show the surface morphologies of two fingers made with the two different glass pastes after firing in a furnace with a peak temperature around $500{ }^{\circ} \mathrm{C}$. As shown in Figure $10 \mathrm{~b}$, the clear edges between the glass paste and the Si substrate demonstrated that a significant reaction had occurred between the glass frit and the passivation stack. After the heat treatment, a full area $\mathrm{Al}$ paste layer was screen printed on the two solar cells and the cells were fired in a furnace. The peak heat treatment temperature was $750{ }^{\circ} \mathrm{C}$. In order to verify directly whether the firing through reaction has occurred, the two Si cells were then etched in $\mathrm{HCl}$ to remove the $\mathrm{Al}$ fingers. Figure 10c, d show the finger morphology after the finger removal. It can be seen that the finger area was uniformly fired through for the glass paste with $30 \%$ solid glass as shown in Figure 10d. For the finger fired with $10 \%$ glass frit, the finger was not uniformly fired through, as shown in Figure 10c. However, the etching reaction was still significant. This was confirmed by the J-V curve measurements, shown in Figure 11a,b. The solar cell short circuit currents were 39.71 and $39.60 \mathrm{~mA} / \mathrm{cm}^{2}$, the $\mathrm{V}_{\text {oc }}$ were 0.6479 and $0.6401 \mathrm{~V}$, the fill factors were $74.6 \%$ and $74.0 \%$, and the efficiency were $19.19 \%$ and $18.76 \%$, for the two solar cells fabricated with $30 \%$ and $10 \%$ solid glass frit, respectively. It can be seen that the $\mathrm{V}_{\mathrm{oc}}$ of the cell using the $10 \%$ glass frit was $7.8 \mathrm{mV}$ lower than that used the $30 \%$ glass frit. This was induced by a relatively high density of spikes observed in the $\mathrm{Si}$ for the 10\% glass frit cell, as shown in Figure 10e. The spikes ran deep into the Si, therefore increasing carrier recombination around the spikes leading to the loss of its $\mathrm{V}_{\mathrm{oc}}$. For the $30 \%$ glass frit cell, the reaction between the $\mathrm{Al}$ paste and the passivation stack was more uniform compared 
to the $10 \%$ glass frit cell, as shown in Figure 10f. This observation was also confirmed by the dark J-V measurements shown in Figure 11b. The 10\% glass frit cell showed an increased leakage current at the reverse applied voltage.
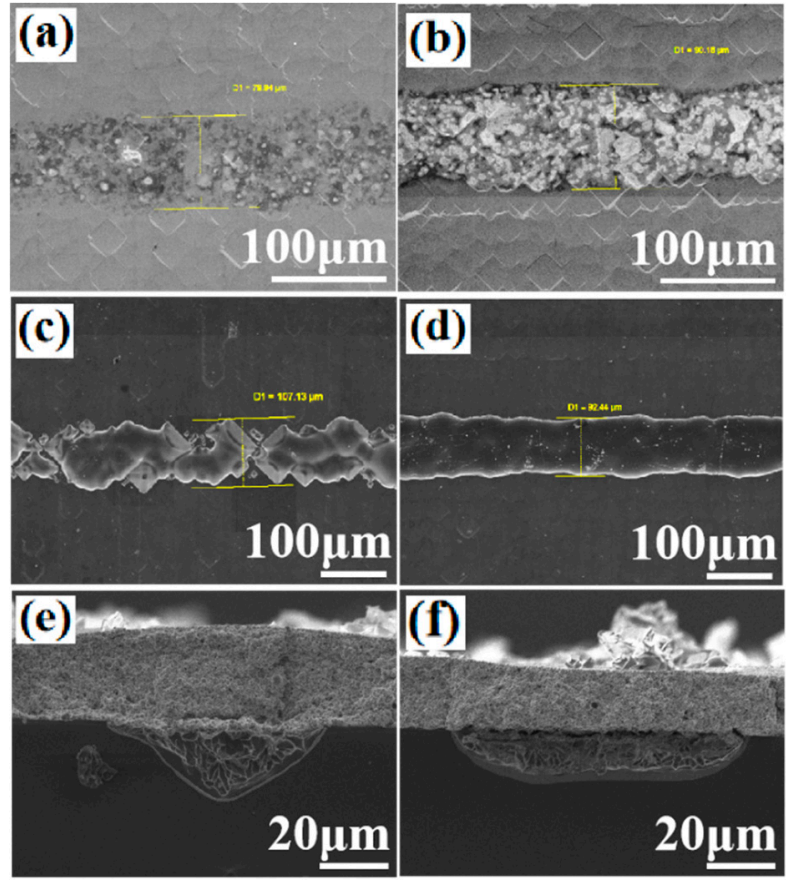

Figure 10. (a,b) SEM surface images obtained using the $10 \%$ and $30 \%$ solid glass frit in the glass pastes; $(\mathbf{c}, \mathbf{d})$ SEM images of the etching area after the Al paste had been removed; $(\mathbf{e}, \mathbf{f})$ cross-sectional SEM images of the contact area.
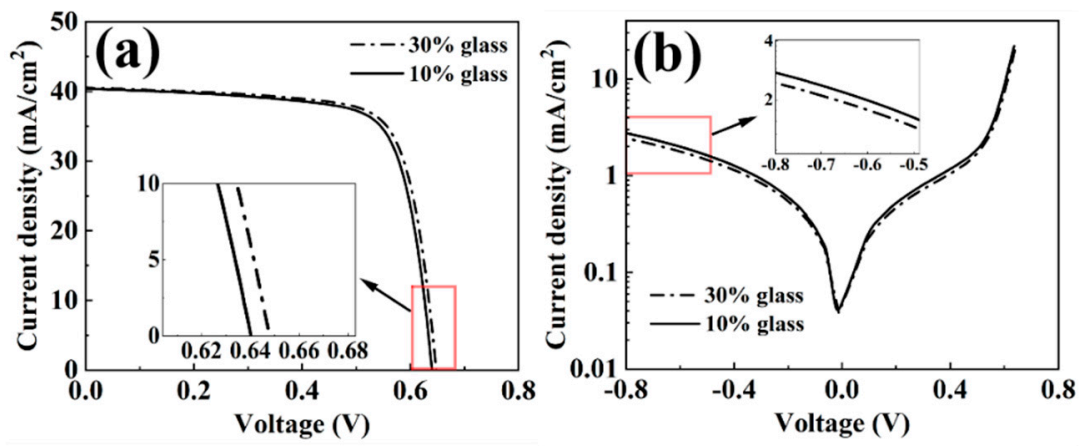

Figure 11. (a,b) Light and dark J-V curves of the cells with $10 \%$ and $30 \%$ solid glass frit in the glass pastes.

In order to reduce carrier recombination at the rear surface of PERC solar cells, point contacts were designed and fabricated with the same paste-etching processes as discussed in Figure 10. The solar cell contact structure and the light $\mathrm{J}-\mathrm{V}$ curve are shown in Figure 12. The solar cell demonstrated a high open-circuit voltage of $0.6534 \mathrm{~V}$, the fill factor was $73.1 \%$, and the efficiency was $19.61 \%$. The dark $\mathrm{J}-\mathrm{V}$ curves of the cells with screen printing firing-through line paste 1 and point contact are shown in Figure $12 \mathrm{~b}$. It can be seen that the Si cell with point contact had lower leakage current, which was ascribed to the reduced rear surface recombination compared to the firing-through paste with line shape. Figure 12e shows the cross-sectional SEM image of one point contact. It was found that $80 \%$ of all the point contacts showed such an inverted pyramid shape. Small contact area and uniform etching for the point contact solar cell led to relatively high open-circuit voltage of $0.6534 \mathrm{~V}$. This $\mathrm{V}_{\mathrm{oc}}$ value is one of the highest values for all the firing through solar cells fabricated in this study. The fill factor 
was relatively low, $73.1 \%$, which was induced by the relatively high series resistance due to the small contact area shows in the Figure 12c.
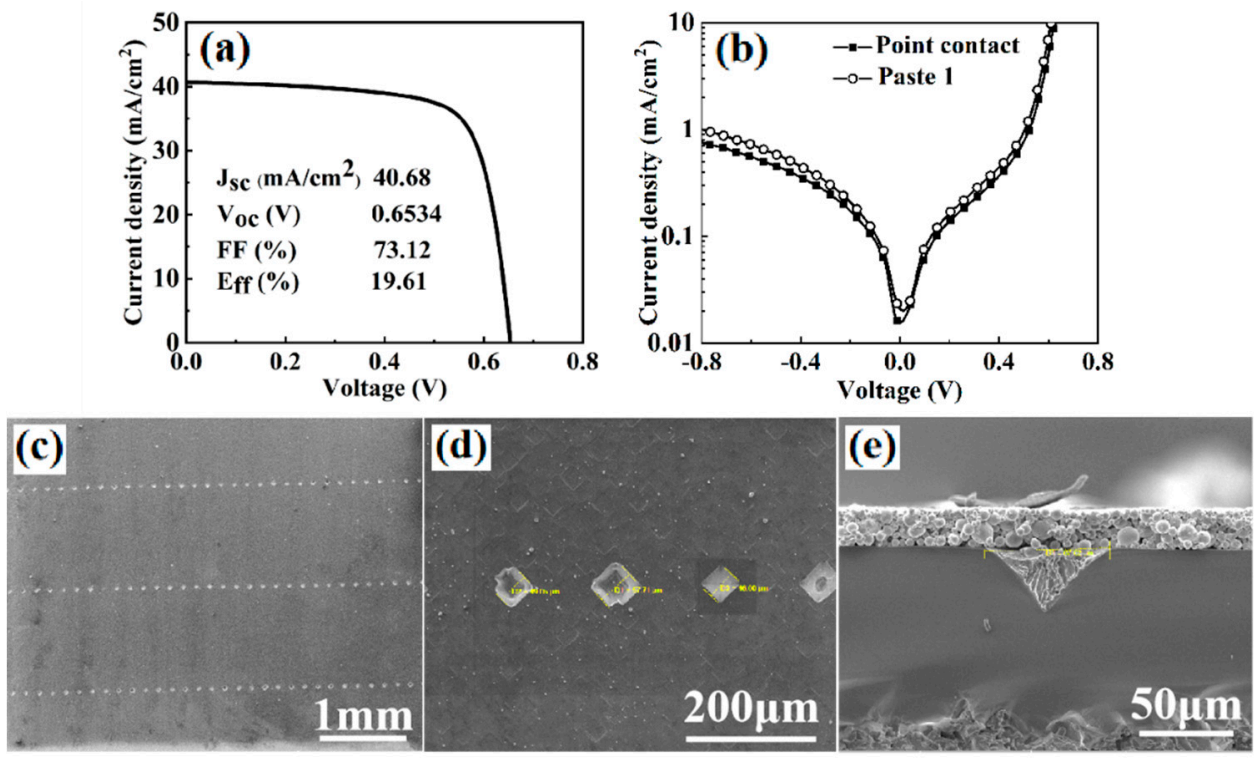

Figure 12. (a) Light J-V curve of a solar cell with point contact; (b) dark J-V curves of the cells obtained with point contact by using paste $1 ;(\mathbf{c}, \mathbf{d})$ SEM surface images of point contact cell and (e) cross-sectional SEM image obtained on one-dot contact.

\section{Conclusions}

In this study, firing-through pastes with different etching capability have been developed and have been applied to achieve metallization contact on the rear side of p-type monocrystalline silicon PERC solar cells. The rear-side passivation layer $\mathrm{Al}_{2} \mathrm{O}_{3}$ and the $\mathrm{SiN}_{\mathrm{x}}$ layer can be effectively etched by the firing-through paste. Ohmic contact with a contact resistivity as low as $1 \mathrm{~m} \Omega \cdot \mathrm{cm}^{2}$ was obtained for the most reactive paste. However, when the metallization contact resistance was low, the open-circuit voltage was also lower than that of the cells with higher metallization contact resistance. A non-uniform etching reaction between the paste and the $\mathrm{Al}_{2} \mathrm{O}_{3} / \mathrm{SiN}_{\mathrm{x}}$ would lead to formation of high-density recombinations at the $\mathrm{Si} /$ paste interface. Small-area patterned dot back contacts can improve the metallization uniformity during the fire-through process. Even though the majority of the dot contacts showed inverted pyramid contact geometry, carrier recombination was reduced due to the small-contact area at the Si/paste interface. A p-type solar cell with an area of $7.8 \times 7.8 \mathrm{~cm}^{2}$ with a $\mathrm{V}_{\mathrm{oc}}$ of $0.6534 \mathrm{~V}$ and an efficiency of $19.61 \%$ was fabricated.

Author Contributions: Conceptualization, G.W. (Guang Wu) and Y.L.; Data curation, G.W. (Guang Wu) and G.Z.; Formal analysis, M.L., M.W. and G.Z.; Funding acquisition, Y.L., P.Z. and D.W.; Investigation, M.L., Y.Z., G.Z. and G.W. (Guangwei Wang); Methodology, Y.L., M.L. and G.W. (Guangwei Wang); Project administration, G.W. (Guang Wu), Y.L., M.L. and M.W.; Resources, Y.Z. and G.W. (Guangwei Wang); Software, Y.Z. and M.W.; Supervision, Y.L., P.Z. and D.W.; Validation, Y.Z.; Writing—original draft, G.W. (Guang Wu); Writing一review \& editing, Y.L., P.Z. and D.W.

Funding: This research was funded by Special Fund for S\&T achievements transformation of Jiangsu province, grant number BA2017117, Science and Technology Program of Nantong (No. JC2018023), Science and Technology program of Jiangsu province, grant number: BY2016053-09, and the National Natural Science Foundation of China (No. 61774140).

Conflicts of Interest: The authors declare no conflict of interest.

\section{References}

1. Blakers, A.W.; Wang, A.; Milne, A.M.; Zhao, J.H.; Green, M.A. 22.8-Percent Efficient Silicon Solar-Cell. Appl. Phys. Lett. 1989, 55, 1363-1365. [CrossRef] 
2. Masuko, K.; Shigematsu, M.; Hashiguchi, T.; Fujishima, D.; Kai, M.; Yoshimura, N.; Yamaguchi, T.; Ichihashi, Y.; Mishima, T.; Matsubara, N.; et al. Achievement of More Than 25\% Conversion Efficiency with Crystalline Silicon Heterojunction Solar Cell. IEEE J. Photovolt. 2014, 4, 1433-1435. [CrossRef]

3. Feldmann, F.; Bivour, M.; Reichel, C.; Steinkemper, H.; Herm, M.; Glunz, S.W. Tunnel oxide passivated contacts as an alternative to partial rear contacts. Sol. Energy Mater. Sol. Cells 2014, 131, 46-50. [CrossRef]

4. Green, M.A. The Passivated Emitter and Rear Cell (PERC): From conception to mass production. Sol. Energy Mater. Sol. Cells 2015, 143, 190-197. [CrossRef]

5. Dullweber, T.; Schmidt, J. Industrial Silicon Solar Cells Applying the Passivated Emitter and Rear Cell (PERC) Concept-A Review. IEEE J. Photovolt. 2016, 6, 1366-1381. [CrossRef]

6. Gatz, S.; Hannebauer, H.; Hesse, R.; Werner, F.; Schmidt, A.; Dullweber, T.; Schmidt, J.; Bothe, K.; Brendel, R. 19.4\%-efficient large-area fully screen-printed silicon solar cells. Phys. Status Solidi-R 2011, 5, 147-149. [CrossRef]

7. Schmidt, J.; Merkle, A.; Brendel, R.; Hoex, B.; van de Sanden, M.C.M.; Kessels, W.M.M. Surface passivation of high-efficiency silicon solar cells by atomic-layer-deposited $\mathrm{Al}_{2} \mathrm{O}_{3}$. Prog. Photovolt. 2008, 16, 461-466. [CrossRef]

8. Kranz, C.; Lim, B.; Baumann, U.; Dullweber, T. Determination of the contact resistivity of screen-printed Al contacts formed by laser contact opening. Energy Procedia 2015, 67, 64-69. [CrossRef]

9. Kim, J.; Hwang, Y.; Kim, J.; Lim, J.; Lee, E. Investigation of rear side selective laser ablation and damage etching process for industrial PERC solar cells. In Proceedings of the 4th International Conference on Crystalline Silicon Photovoltaics (Siliconpv 2014), 's-Hertogenbosch, The Netherlands, 25-27 March 2014; Volume 55, pp. 791-796.

10. Kim, J.; Kim, J.; Lim, J.Y.; Hwang, Y.; Cho, J.; Choi, H.; Lee, E. Laser ablation of aluminum oxide and silicon nitride rear-side passivation for i-PERC cell. Renew. Energy 2015, 79, 135-139. [CrossRef]

11. Meemongkolkiat, V.; Nakayashiki, K.; Kim, D.S.; Kim, S.; Shaikh, A.; Kuebelbeck, A.; Stockum, W.; Rohatgi, A. Investigation of modified screen-printing al pastes for local back surface field formation. World Con. Photovolt. E 2006, 2, 1338-1341.

12. Muller, J.; Bothe, K.; Gatz, S.; Plagwitz, H.; Schubert, G.; Brendel, R. Contact Formation and Recombination at Screen-Printed Local Aluminum-Alloyed Silicon Solar Cell Base Contacts. IEEE T Electron. Dev. 2011, 58, 3239-3245. [CrossRef]

13. Rauer, M.; Woehl, R.; Ruhle, K.; Schmiga, C.; Hermle, M.; Horteis, M.; Biro, D. Aluminum Alloying in Local Contact Areas on Dielectrically Passivated Rear Surfaces of Silicon Solar Cells. IEEE Electr. Device L 2011, 32, 916-918. [CrossRef]

14. Lennon, A.J.; Ho-Baillie, A.W.Y.; Wenham, S.R. Direct patterned etching of silicon dioxide and silicon nitride dielectric layers by inkjet printing. Sol. Energy Mater. Sol. Cells 2009, 93, 1865-1874. [CrossRef]

15. Lee, S.H. Cost effective process for high-efficiency solar cells. Sol. Energy 2009, 83, 1285-1289. [CrossRef]

16. Du, Z.R.; Palina, N.; Chen, J.; Hong, M.H.; Hoex, B. Rear-Side Contact Opening by Laser Ablation for Industrial Screen-Printed Aluminium Local Back Surface Field Silicon Wafer Solar. In Pv Asia Pacific Conference 2011; Luther, J., Ed.; Elsevier Science Bv: Amsterdam, The Netherlands, 2012; Volume 25, pp. $19-27$.

17. Riegel, S.; Mutter, F.; Lauermann, T.; Terheiden, B.; Hahn, G. Review on screen printed metallization on p-type silicon. In Proceedings of the Third Metallization Workshop on Metallization for Crystalline Silicon Solar Cells, Charleroi, Belgium, 25-26 October 2011; Volume 21, pp. 14-23.

18. Beaucarne, G.; Choulat, P. In Local Al-alloyed contacts for next generation Si solar cells. In Proceedings of the 24th European Photovoltaic Solar Energy Conference and Exhibition, Hamburg, Germany, 21-25 September 2009.

19. Lin, C.-M.; Fang, T.; Li, K.-J.; Wang, L.-T.; Tang, W.-C. Metallization of rear-side passivated cells: Reducing cavities on local contacts. In Proceedings of the 26th European Photovoltaic Solar Energy Conference and Exhibition, Hamburg, Germany, 5-9 September 2011.

20. Picard, E.; Pirot, M.; Monna, R.; Dubois, S. Rear-surface laser contact opening design optimization for PERC solar cells. In Proceedings of the 33rd European Photovoltaic Solar Energy Conference and Exhibition, Amsterdam, the Netherlands, 25-29 September 2017; pp. 641-645.

21. Yung-Sheng, L.; Ting-Wei, G.; Tsung-Cheng, C.; Chen-Hao, K.; Lee, J.J. Optimization of the rear side opening pattern for PERC solar cell. In Proceedings of the IEEE 39th Photovoltaic Specialists Conference (PVSC), Tampa, FL, USA, 16-21 June 2013; pp. 1602-1606. 
22. Bahr, M.; Heinrich, G.; Doll, O.; Kohler, I.; Maier, C.; Lawerenz, A. Differences of rear-contact area formation between laser ablation and etching paste for PERC solar cells. In Proceedings of the E-MRS Spring Meeting 2015 Symposium C-Advanced inorganic materials and structures for photovoltaics, San Francisco, CA, USA, 6-10 April; pp. 1203-1209.

23. Rauer, M.; Schmiga, C.; Woehl, R.; Ruhle, K.; Hermle, M.; Horteis, M.; Biro, D.; Glunz, S.W. Investigation of Aluminum-Alloyed Local Contacts for Rear Surface-Passivated Silicon Solar Cells. IEEE J. Photovolt. 2011, 1, 22-28. [CrossRef]

24. Thaidigsmann, B.; Kick, C.; Drews, A.; Clement, F.; Wolf, A.; Biro, D. Fire-through contacts-a new approach to contact the rear side of passivated silicon solar cells. Sol. Energy Mater. Sol. Cells 2013, 108, 164-169. [CrossRef]

25. Rudolph, D.; Buck, T.; Teppe, A.; Masouleh, F.B.; Harney, R. Firing through aluminum grid paste for bifacial solar cells. In Proceedings of the 6th International Conference on Crystalline Silicon Photovoltaics (Siliconpv 2016), Chambéry, France, 9-10 March 2016; Volume 92, pp. 971-977.

26. Navarrete, E.; Kimmerle, A.; Thaidigsmann, B.; Woehl, R.; Ramos-Barrado, J.R.; Biro, D. Evaluation of fire-through aluminum pastes for local contact formation in silicon solar cells. In Proceedings of the 28th European Photovoltaic Solar Energy Conference and Exhibition, Paris, France, 30 September-4 October 2013; pp. 1839-1841.

27. Song, J.Y.; Park, S.; Kim, Y.D.; Kang, M.G.; Tark, S.J.; Kwon, S.; Yoon, S.; Kim, D. Aluminum fire-through with different types of the rear passivation layers in crystalline silicon solar cells. Met. Mater. Int. 2012, 18, 699-703. [CrossRef]

(C) 2019 by the authors. Licensee MDPI, Basel, Switzerland. This article is an open access article distributed under the terms and conditions of the Creative Commons Attribution (CC BY) license (http://creativecommons.org/licenses/by/4.0/). 